\title{
Hubungan Penggunaan Smartphone pada Malam Hari Terhadap Kualitas Tidur Mahasiswa Program Studi Pendidikan Dokter Fakultas Kedokteran
} Universitas Andalas

\author{
Nika Fitri ${ }^{1}$, Fathiya Juwita Hanum ${ }^{2}$, Mohamad Reza ${ }^{3}$ \\ ${ }^{1}$ Profesi Dokter FK UNAND (Fakultas Kedokteran Universitas Andalas Padang) \\ ${ }^{2}$ Bagian Radioterapi RS UNAND / RSUP Dr. M. Djamil Padang \\ ${ }^{3}$ Bagian Biologi FK UNAND
}

\author{
A B S T R A C T
}

\begin{abstract}
Latar Belakang: Smartphone adalah telepon yang menggabungkan kemampuan-kemampuan canggih dan merupakan bentuk lanjutan dari Wireless Mobile Device (WMD) yang bisa berfungsi seperti komputer dengan menawarkan fitur-fitur yaitu Personal Digital Assistant (PDA), akses internet, e-mail, dan Global Positioning System (GPS). Indonesia merupakan pengguna aktif smartphone terbesar keempat di dunia setelah Cina, India, dan Amerika. Smartphone dilengkapi dengan tampilan light-emitting diode (LED) yang dapat menyebabkan penekanan produksi melatonin pada malam hari dan mempengaruhi regulasi sirkadian dari siklus tidur-bangun, sehingga mempengaruhi kualitas tidur. Objektif: Mengetahui hubungan penggunaan smartphone pada malam hari terhadap kualitas tidur mahasiswa program studi Pendidikan Dokter Fakultas Kedokteran Universitas Andalas. Metode: Penelitian menggunakan metode analitik dengan desain cross-sectional yang dilakukan di Fakultas Kedokteran Universitas Andalas pada bulan Oktober 2019 - Juni 2020 . Teknik pengambilan sampel adalah stratified random sampling dengan jumlah total 261 sampel.
\end{abstract}

Hasil: Penggunaan smartphone pada malam hari $<2$ jam $(11,1$ $\%),>2$ jam (88,9\%), kualitas tidur baik $(37,9 \%)$, kualitas tidur buruk $(62,1 \%)$. Hasil analisis bivariat didapatkan nilai p-value $0,024(<0,05)$ yang berarti terdapat hubungan yang bermakna antara penggunaan smartphone pada malam hari terhadap kualitas tidur mahasiswa Pendidikan Dokter Fakultas Kedokteran Universitas Andalas.

Kesimpulan: Terdapat hubungan yang bermakna antara penggunaan smartphone pada malam hari terhadap kualitas tidur mahasiswa program studi Pendidikan Dokter Fakultas Kedokteran Universitas Andalas.

Kata Kunci: kualitas tidur, Smartphone

Background: Smartphone combines advanced capabilities and is an advanced form of Wireless Mobile Device (WMD) that have functions like a computer by offering features such as Personal Digital Assistant (PDA), internet access, e-mail, and Global Positioning System (GPS). Indonesia is fourth largest active smartphone user in the world after China, India and
America. Smartphones equipped with light-emitting diode (LED) displays that can cause suppression of melatonin production at night and affect the circadian regulation of the sleep-wake cycle, thus affecting sleep quality.

Objective: To determine the relationship of smartphone use at night to the sleep quality of students of the Medical Education study program at the Andalas University Faculty of Medicine. Methods: This research used analytic methods with crosssectional design conducted at the Faculty of Medicine, Andalas University in October 2019 - June 2020. The sampling technique is stratified random sampling with a total sample of 261 samples.

Results: Smartphone use at night $<2$ hours (11.1\%), > 2 hours (88.9\%), good sleep quality (37.9\%), poor sleep quality (62.1\%). The bivariate analysis results obtained $p$-value of 0.024 (<0.05) which means there is a significant relationship between the use of smartphones at night to the sleep quality of 2017, 2018 and 2019 students of Medical Education, Faculty of Medicine, Andalas University.

Conclusions: The conclusion of this study found a significant relationship between the use of smartphones at night to the sleep quality of students of the Medical Education study program at the Faculty of Medicine, Andalas University.

Keywords: sleep quality, Smartphone

\section{Apa yang sudah diketahui tentang topik ini?}

Terdapat berbagai faktor yang bisa mempengaruhi kualitas tidur yaitu usia, kelelahan, stress psikologi, lingkungan, konsumsi obat-obatan, diet dan gaya hidup

Apa yang ditambahkan pada studi ini?

Penggunaan smartphone pada malam hari yang bisa mempengaruhi kualitas tidur.

\section{CORRESPONDING AUTHOR}

Phone: +6282288512940

E-mail: fitrinika955@gmail.com 


\section{Pendahuluan}

Smartphone adalah telepon yang menggabungkan kemampuan-kemampuan canggih dan merupakan bentuk lanjutan dari Wireless Mobile Device (WMD) sehingga memiliki fungsi yang sama dengan komputer yang menawarkan berbagai macam fitur seperti Personal Digital Assistant (PDA), Global Positioning System (GPS), akses internet hingga e-mail. Selain itu juga memiliki fitur lain seperti kamera, video, pemutar audio dan fungsi ponsel sebagai alat komunikasi. $^{2}$

Pada tahun 2016 tercatat sebanyak 2,5 miliar orang menggunakan smartphone, tahun 2017 sebanyak 2,7 miliar pengguna, tahun 2018 sebanyak 2,9 miliar pengguna dan 2019 tercatat 3,2 miliar orang pengguna smartphone. ${ }^{12}$ Indonesia merupakan negara dengan pengguna aktif smartphone terbesar yang berada pada posisi keempat di dunia setelah Cina, India, dan Amerika. ${ }^{17}$

Smartphone seringkali dilengkapi dengan tampilan light-emitting diode (LED), yang menghadirkan cahaya terang bagi mata manusia. LED pada smartphone adalah sumber penting cahaya buatan di malam hari, hal tersebut juga mempengaruhi regulasi sirkadian dari siklus tidur-bangun. ${ }^{9}$ Dioda LED dapat memancarkan cahaya biru dan putih, yang berbahaya dan bisa menjadi toksisitas okular dengan risiko mengembangkan katarak atau degenerasi makula yang berhubungan dengan iluminasi retina. Menonton layar dengan cahaya LED selama berjam-jam yang ditempatkan pada jarak $30 \mathrm{~cm}$ dari mata berpotensi sangat berbahaya untuk mata dengan panjang gelombang antara 415 dan $455 \mathrm{~nm} .{ }^{21}$ Setelah 1 jam paparan LED bercahaya sendiri tidak menyebabkan penekanan melatonin yang berbeda secara signifikan. Namun perbedaan ini mencapai signifikansi setelah 2 jam paparan. ${ }^{26}$

Melatonin adalah hormon yang dihasilkan oleh kelenjar pineal. Hormon melatonin merupakan hormon kegelapan dan memiliki fungsi utama untuk menjaga irama sirkadian tubuh sesuai dengan dengan siklus terang (periode aktivitas)-gelap (periode istirahat) dalam 24 jam. Sekresi melatonin akan meningkat sepuluh kali lipat pada malam hari dan akan turun pada saat siang hari.28

Kualitas tidur (quality of sleep) merupakan kemampuan individu untuk tetap pada keadaan tidur dan bangun dengan jumlah pola tidur NREM dan REM yang cukup. ${ }^{19}$ Faktor-faktor yang mempengaruhinya adalah :

a. Usia

Semakin bertambah usia periode tidur semakin menurun dan berpengaruh terhadap kualitas tidur. Kualitas tidur pada lansia terjadi karena proses penuaan yang menyebabkan terjadinya perubahan pada waktu istirahat dan pola tidurnya. ${ }^{7}$

b. Kelelahan

Ketika seseorang mengalami kelelahan, itu akan berdampak terhadap kulitas tidur yang buruk. ${ }^{22}$

c. Stres Psikologis

Pada sistem ARAS (Ascending Reticulary Activity System) akan mempengaruhi keadaan tidur/terjaganya seseorang. Aktivitas ARAS dipengaruhi oleh aktifitas neurotransmiter, salah satu aktivitas neorotransmiternya adalah sistem serotonergik. Jumlah serotonin dipengaruhi oleh metabolisme asam amino trypthopan, jika trypthopan meningat maka serotonin juga meningkat. Ketika serotonin meningkat akan membuat seseorang mearasa nyaman dan mudah untuk tertidur. Begitu juga sebaliknya, ketika produksi serotoninnya berkurang akan membuat seseorang merasa tidak nyaman atau waspada hingga sulit untuk tertidur. ${ }^{13}$

d. Lingkungan

Kondisi lingkungan yang bisa mempengaruhi proses tidur seseorang yaitu suara bising, posisi tempat tidur dan sistem pencahayaan yang tidak baik. ${ }^{19}$ Suara bising yang dihasilkan akan ditangkap oleh indera pendengaran dan diteruskan ke otak, sehingga rangsangan eksternal tersebut memungkinkan seseorang akan terbangun jika mendengar suara bising meskipun sudah memasuki tahap tidur dalam. Pencahayaan yang dikatakan adalah cahaya dari lampu yang bisa menembus kelopak mata yang 
kemudian merangsang otak seseorang untuk tetap beraktivitas meskipun dalam kondisi mata terpejam. Proses tersebut mempengaruhi produksi hormon melatonin yang hanya bisa dihasilkan dalam kondisi gelap. ${ }^{23}$ Selain itu paparan cahaya LED dari smartphone pada malam hari dapat menyebabkan penekanan produksi melatonin yang ditandai oleh waktu yang lama untuk timbulnya melatonin, mengurangi rasa kantuk. ${ }^{10}$

e. Obat-obatan

Mengkonsumsi obat-obatan seperti obat antidepresan, antiepilepsi dan antitiroid dapat memberikan efek samping rasa mengantuk. Konsumsi obat tidur seperti Diphenhydramine, Doxylamine dan Acetaminophen juga dapat menyebabkan membaiknya kualitas tidur seseorang yang sebenarnya memiliki gangguan tidur. Hal ini akan menimbulkan bias pada penelitian. ${ }^{8}$ Antidepresan dan stimulant dapat menekan tidur REM (Rapid Eye Movement) dan menurunkan total waktu tidur. Selanjutnya Narkotika dapat menekan tidur REM (Rapid Eye Movement) yang menyebabkan peningkatan perasaan kantuk pada siang hari. ${ }^{19}$

f. Diet

Mengkonsumsi makanan atau minuman yang mengandung kafein dan mengkonsumsi alkohol sebelum tidur. Kafein dapat membuat seseorang dalam keadaan terjaga dan mencegah untuk tertidur, lalu dapat menyebabkan seseorang terbangun di malam hari. Sedangkan alkohol bisa mempercepat mulainya tidur, lalu mengganggu tidur REM (Rapid Eye Movement), sehingga membangunkan seseorang pada malam harinya dan menyebabkan kesulitan untuk tertidur kembali. ${ }^{19}$ Mengkonsumsi $400 \mathrm{mg}$ kafein dalam 3 atau bahkan 6 jam sebelum waktu tidur secara signifikan mengganggu tidur. Bahkan pada 6 jam, kafein mengurangi tidur lebih dari 1 jam. 6

g. Gaya Hidup

Rutinitas harian seseorang bisa mempengaruhi pola dan jam internal tidur yang sudah diatur oleh tubuh. Misalkan seseorang yang bekerja 1 minggu siang dan 1 minggu malam, sehingga mempunyai kesulitan menyesuaikan perubahan jadwal tidur. Namun setelah beberapa minggu bekerja pada malam hari, biasanya dapat disesuaikan jam biologis seseorang. ${ }^{19}$

Selain rutinitas harian, kualitas tidur seseorang dapat juga dipengaruhi oleh kebiasaan mnggunakan smartphone. Umi Romayati Keswara menyatakan bahwa hubungan perilaku penggunaan smartphone dengan kualitas tidur yaitu disebabkan karena terganggunya jadwal tidur oleh penggunaan smartphone pada malam hari. Selain itu tidur berdekatan dengan smartphone dalam keadaan aktif juga bisa mempengaruhi kualitas tidur. Hal tersebut dikarenakan smartphone yang aktif dapat berdering ataupun bergetar ketika adanya notifikasi yang masuk, sehingga otak akan bersiaga menerima stimulus dari luar yang berupa suara, cahaya, dan getaran dari smartphone tersebut, lalu otak akan mengirimkan sinyal tersebut sehingga menyebabkan seseorang terjaga pada malam hari dan menyebabkan otak terus waspada tanpa disadari. Maka dapat disimpulkan bahwa tidur berdekatan dengan smartphone yang aktif dapat mempengaruhi kualitas tidur seseorang. ${ }^{15}$

\section{Metode}

Jenis penelitian yang digunakan adalah penelitian analitik dengan pendekatan cross sectional. Jumlah sampel adalah 261 orang siswa. Pengambilan sampel dilakukan secara stratified random sampling dengan menggunakan rumus pengambilan sampel tiap tingkat. Variabel dependennya adalah kualitas tidur mahasiswa Profesi Dokter Universitas Andalas dan variable independennya adalah penggunaan smartphone pada malam hari. Penelitian dilakukan dari bulan Oktober 2019 - Juni 2020 di Fakultas Kedokteran Universitas Andalas, Padang, Sumatera Barat.

Populasi penelitian ini adalah mahasiswa angkatan 2017, 2018, 2019 di Fakultas Kedokteran Universitas Andalas. Sampel penelitian yang dipilih adalah mahasiswa angkatan 2017, 2018, 2019 Fakultas Kedokteran Universitas Andalas yang memenuhi kriteria inklusi dan tidak memiliki kriteria eksklusi. Kriteria inklusi subjek: Responden adalah mahasiswa program studi Pendidikan Dokter 
Fakultas Kedokteran Universitas Andalas; responden menggunakan smartphone; bersedia menjadi responden dalam penelitian. Kriteria eksklusi subjek: Responden tidak hadir saat pengambilan kuesioner; mengkonsumsi obatobatan (obat tidur, antidepresan, antiepilepsi, antitiroid, antikanker, glukokortikoid atau obat pelangsing); mengalami Stress psikologis; mengkonsumsi kafein dan alkohol.

Data diperoleh dengan cara pengisian kuesioner oleh responden. Kuesioner yang digunakan adalah Menilai kualitas tidur dengan kuesioner PSQI (Pittsburgh Sleep Quality Index) melalui 7 komponen. interpretas i : $\leq 5$ untuk Kualitas tidur baik dan $>5$ untuk Kualitas tidur buruk. Sedangkan interpretasi penggunaan smartphone : $<2$ jam untuk cukup dan $\geq 2$ jam untuk penggunaan lama. ${ }^{25}$

Data dianalisis secara statistik berdasarkan variabel yang dinilai menggunakan sistem komputerisasi yaitu analisis univariat dan bivariat. Analisis univariat dilakukan terhadap variabel independen (Penggunaan smartphone) dan dependen (Kualitas tidur). Analisis ini akan menghasilkan distribusi dan presentase dari tiap variabelnya. bertujuan untuk menguji hipotesis serta melihat hubungan antara variabel independen (Penggunaan smartphone) terhadap dependen (Kualitas tidur) dengan metode uji statistik chi square. Nilai yang digunakan yaitu pvalue, 95\% confidence interval. Perhitungan statistik ini akan bermakna jila nilai $\mathrm{p}<0,05$ dan nilai 95\% confidence interval tidak melewati angka satu. ${ }^{24}$. Penelitian ini telah lulus kaji etik dengan nomor surat: 233/KEPK/2020 dari bagian etik RSUP Dr. M.Djamil Padang.

\section{Hasil}

Penelitian ini dilakukan pada mahasiswa Pendidikan Dokter Fakultas Kedokteran Universitas Andalas, yang bertujuan untuk melihat hubungan antara penggunaan smartphone pada malam hari dengan kualitas tidur. Sampel pada penelitian ini berjumlah sebanyak 261 responden yang terdiri 88 responden dari angkatan 2017, 85 responden dari angkatan 2018 dan 88 responden dari angkatan 2019.
1. Karakteristik Responden

Tabel 1. Karakteristik Responden

\begin{tabular}{lcc}
\hline \multicolumn{1}{c}{ Karakteristik } & Frekuensi & $\mathbf{\%}$ \\
\hline Usia & & \\
15 tahun & 1 & 0,4 \\
16 tahun & 1 & 0,4 \\
17 tahun & 8 & 3,1 \\
18 tahun & 40 & 15.3 \\
19 tahun & 83 & 31,8 \\
20 tahun & 94 & 36,0 \\
21 tahun & 32 & 12,3 \\
22 tahun & 2 & 0,8 \\
\hline Total & 261 & 100 \\
\hline Jenis Kelamin & & \\
Laki-laki & 75 & 28,7 \\
Perempuan & 186 & 71,3 \\
\hline Total & 261 & 100 \\
\hline Angkatan & & \\
Angkatan 2017 & 88 & 33,7 \\
Angkatan 2018 & 85 & 32,6 \\
Angkatan 2019 & 88 & 33,7 \\
\hline Total & 261 & 100 \\
\hline
\end{tabular}

Berdasarkan Tabel 5.1 di atas didapatkan bahwan responden yang berusia 15 tahun 1 orang, 16 tahun 1 orang, 17 tahun sebanyak 8 orang, 19 tahun sebanyak 83 orang, 20 tahun sebanyak 94 orang, 21 tahun sebanyak 32 orang dan usia 22 tahun sebanyak 2 orang. Jenis kelamin responden di dominasi oleh perempuan Penelitian yaitu sebanyak 186 orang $(71,3 \%)$ dari total responden dan laki-laki sebanyak 75 orang $(28,7 \%)$. Sedangkan data untuk angkatan didapatkan bahwa angkatan 2017 sebanyak 88 responden, angkatan 2018 sebanyak 85 responden dan angkatan 2019 sebanyak 88 responden.

\section{Distribusi Frekuensi Penggunaan Smartphone Pada Malam Hari Subjek Penelitian}

Tabel 2 Lama Penggunaan Smartphone pada

\begin{tabular}{lcc}
\multicolumn{2}{c}{ Malam Hari } & \\
\hline $\begin{array}{c}\text { Penggunaan } \\
\text { Smartphone pada } \\
\text { Malam Hari }\end{array}$ & Frekuensi & $\mathbf{\%}$ \\
\hline$<2$ jam & 29 & 11,1 \\
$>2$ jam & 232 & 88,9 \\
\hline Total & 261 & 100 \\
\hline
\end{tabular}

Hasil dari penelitian ini didapatkan bahwa sebanyak 232 orang $(88,9 \%)$ dari total sampel menggunakan smartphone $>2$ jam pada malam hari. Sedangkan 29 orang (11,1 \%) lainnya menggunakan samrtphone $<2$ jam pada malam hari. 


\section{Distribusi Frekuensi Kualitas Tidur Subjek Penelitian}

Tabel 3. Kualitas Tidur Subjek Peneitian

\begin{tabular}{lcc}
\hline \multicolumn{1}{c}{ Kualitas Tidur } & Frekuensi & $\mathbf{\%}$ \\
\hline Baik & 99 & 37,9 \\
Buruk & 162 & 62,1 \\
\hline Total & 261 & 100 \\
\hline
\end{tabular}

Berdasarkan tabel di atas, hasil penelitian ini didapatkan bahwa sebagian besar mahasiswa Pendidikan Dokter Fakultas Kedokteran Universitas Andalas memiliki kualitas tidur yang buruk. Responden yang memiliki kualitas tidur buruk sebanyak 162 responden $(62,1 \%)$ dari total 261 responden. Sedangkan 99 (37,9\%) responden lainnya memiliki kualitas tidur yang baik.

\section{Hubungan Penggunaan Smartphone pada Malam Hari Terhadap Kualitas Tidur}

Tabel 4 Hubungan Penggunaan Smartphone pada Malam Hari Terhadap Kualitas Tidur

\begin{tabular}{|c|c|c|c|c|c|c|c|}
\hline \multirow{3}{*}{$\begin{array}{c}\text { Penggunaan } \\
\text { Smartphone } \\
\text { pada Malam } \\
\text { Hari }\end{array}$} & \multicolumn{4}{|c|}{ Kualitas Tidur } & \multicolumn{2}{|c|}{ Total } & \multirow[t]{3}{*}{ p-value } \\
\hline & \multicolumn{2}{|c|}{ Baik } & \multicolumn{2}{|c|}{ Buruk } & \multirow[b]{2}{*}{$\mathrm{F}$} & \multirow[b]{2}{*}{$\%$} & \\
\hline & $\bar{F}$ & $\%$ & $\bar{F}$ & $\%$ & & & \\
\hline$<2 \mathrm{jam}$ & 17 & 58,6 & 12 & 41,4 & 29 & 100 & \\
\hline$>2 \mathrm{jam}$ & 82 & 35,3 & 150 & 64,7 & 232 & 100 & 0,024 \\
\hline Total & 99 & 37,9 & 162 & 62,1 & 261 & 100 & \\
\hline
\end{tabular}

Metode uji statistik chi-square untuk menguji hipotesis serta melihat hubungan antara variabel independen (Penggunaan smartphone pada malam hari) terhadap dependen (Kualitas tidur). Nilai yang digunakan yaitu p-value, 95\% confidence interval. Perhitungan statistik ini akan bermakna jila nilai $\mathrm{p}<0,05$ dan nilai $95 \%$. Pada penelitian ini didapatkan nilai p-value 0,024 yaitu terdapat hubungan yang bermakna antara penggunaan smartphone pada malam hari terhadap kualitas tidur mahasiswa angkatan 2017, 2018 dan 2019 Pendidikan Dokter Fakultas Kedokteran Universitas Andalas.

\section{Pembahasan}

Hasil univariat dari penelitian ini menunjukkan frekuensi penggunaan smartphone pada malam hari mahasiswa profesi Pendidikan Dokter Fakultas Kedokteran Universitas Andalas, sebanyak 29 (11,1\%) responden menggunakan smartphone $<2$ jam pada malam hari dan 232
$(88,9 \%)$ responden lainnya menggunakan smartphone $>2$ jam pada malam hari. Hal ini dapat disimpulkan bahwa sebagian besar responden menggunakan smartphone $>2$ jam pada malam hari. Sedangkan kualitas tidur diketahui bahwa $162(62,1 \%)$ responden memiliki kualitas tidur buruk. Sedangkan 99 (37,9\%) responden lainnya memiliki kualitas tidur yang baik. Berdasarkan hasil penelitian tersebut menunjukkan mahasiswa yang memiliki kualitas tidur buruk lebih banyak dari pada mahasiswa yang memiliki kualitas tidur baik. Komponen yang paling berpengaruh terhadap kualitas tidur pada penelitian ini adalah komponen durasi tidur, sedangkan komponen dengan korelasi terendah adalah penggunaan obat tidur.

Sedangkan analisis bivariat pada penelitian ini menggunakan metode uji statistik chi-square untuk menguji hipotesis serta melihat hubungan antara variabel independen (Penggunaan smartphone pada malam hari) terhadap dependen (Kualitas tidur). Nilai yang digunakan yaitu p-value, 95\% confidence interval. Perhitungan statistik ini akan bermakna jila nilai $\mathrm{p}$ $<0,05$ dan nilai 95\%. Hasil dari penelitian ini menunjukkan nilai p-value 0,024 yaitu terdapat hubungan yang bermakna antara penggunaan smartphone pada malam hari terhadap kualitas tidur mahasiswa Pendidikan Dokter Fakultas Kedokteran Universitas Andalas

Fairuszita memaparkan bahwa selain sebagai alat penunjang untuk belajar, smartphone juga alat penunjang dalam kegiatan-kegiatan keorganisasian di kampus, seperti sumber penyebaran informasi kegiatan, dan diskusi (net meeting) yang menyebabkan mahasiswa semakin membutuhkan smartphone, tablet, ataupun $p c .^{8}$ Menurut Buchholz yang melakukakan penelitian dengan responden mahasiswa kedokteran dan dokter prakter pada tahun 2016, manfaat utama dari menggunakan smartphone adalah akses yang cepat dan mudah, dan kemampuan untuk melakukan perhitungan medis dengan mudah. Selain itu juga dimanfaatkan sebagai tempat menyimpan data dan informasi kesehatan secara personal, digunakan sebagai alat untuk berkonsultasi dengan profesional kesehatan lainnya dengan menggunakan video, gambar, atau melalui pesan teks. Smartphone juga digunakan sebagai referensi sehingga mahasiswa kedokteran memiliki kemudahan untuk 
mengakses kembali aplikasi yang dibutuhkan melalui smartphone. ${ }^{3}$

Pada smartphone tedapat cahaya biru yang dihasilkan dari LED (Light Emitting Diode) yang dapat menekan sekresi melatonin pada malam hari serta mengganggu irama sirkadian dan menurunkan tingkat kewaspadaan di pagi harinya. ${ }^{4}$ Przybylski peneliti dari Universitas Oxford mengatakan bahwa penggunaan layar digital seperti komputer dan televisi lebih dari 4 jam dalam sehari dan penggunaan smartphone di atas 1 jam 57 menit penggunaan di anggap mampu mengganggu kinerja otak remaja.20 penggunaan smarphone yang tinggi secara signifikan menunjukkan tingkat depresi yang lebih tinggi. Akibatnya, depresi menjadi mediator antara penggunaan smartphone yang berlebihan terhadap kualitas tidur yang buruk. Penelitian ini dilakukan di Süleyman Demirel University dan 400 mahasiswa dipilih secara acak untuk menjadi respondennya. 5

kecanduan smartphone bisa menyebabkan kualitas tidur yang buruk. Hal tersebut terjadi dikarenakan ada yang mempengaruhi yaitu waktu jatuh tidur yang lebih lama, durasi tidur yang berkurang serta adanya gangguan ketika tidur yang terjadi paling tidak satu kali dalam seminggu. Gangguan tidur yang terjadi karena mimpi buruk, terbangun tengah malam, terbangun untuk ke kamar mandi dan kepanasan/kedinginan. Selain itu juga terjadi gangguan aktivitas atau disfungsi pada siang hari satu hingga 2 kali dalam seminggu dikarenakan rasa kantuk. ${ }^{1}$

Terjadinya peningkatan waktu penggunaan smartphone sebagai aktivitas pada malam hari oleh remaja yang mulai memberikan efek terhadap pola tidur dan aktivitas di siang hari. Penelitian di Australia ini menyatakan bahwa 71\% remaja dilaporkan tidur pada malam hari yang tidak optimal akibat penggunaan smartphone pada malam hari sebelum tidur. ${ }^{16}$ ketika remaja menggunakan smartphone pada malam hari dan sebelum tidur bisa mempengaruhi kualitas tidurnya, hal tersebut dikarenakan bisa membuat remaja menunda waktu tidur dan kesulitan untuk memulai tidur kembali. ${ }^{14}$

Penggunaan smartphone lebih dari 3-4 jam dalam sehari dapat menyebabkan timbulnya gejala fisik seperti sakit kepala, merasa kelelahan, nyeri pada leher, nyeri pada bahu, nyeri pada lengan, nyeri pada punggung atau jari, mata terasa kering, dan lain sebagainya. ${ }^{11}$

\section{Simpulan}

Berdasarkan hasil penelitian ini maka dapat disimpulkan sebagian besar mahasiswa Pendidikan Dokter Fakultas Kedokteran Universitas Andalas menggunakan smartphone $>2$ jam dan mahasiswa yang memiliki kualitas tidur buruk lebih banyak dibadingkan kualitas tidur yang baik. Terdapat hubungan yang bermakna antara penggunaan smartphone pada malam hari terhadap kualitas tidur mahasiswa Program Studi Pendidikan Dokter Fakultas Kedokteran Universitas Andalas.

\section{Daftar Pustaka}

1. Ahmar GH. Hubungan kecanduan penggunaan smartphone dengan kualitas tidur pada remaja di SMAN 9 padang tahun 2016. Padang: Universitas Andalas; 2016.

2. Backer E. Using smartphones and Facebook in a major assessment: the student experience. Business Education \& Scholarship of Teaching. 2010 Mar 25;4:21.

3. Buchholz A, Perry B, Weiss LB, Cooley D. Smartphone Use and Perceptions among Medical Students and Practicing Physicians. Journal MTM. 2016; 5 (1):27-32.

4. Chang AM, Aeschbach D, Duffy JF, Czeisler CA. Evening use of light-emitting eReaders negatively affects sleep, circadian timing, and next-morning alertness. PNAS. 2015 January 27;112(4):1232-7.

5. Demirci K, Akgönül M, Akpinar A. Relationship of smartphone use severity with sleep quality, depression, and anxiety in university students. Journal of Behavioral Addictions. 2015; 4(2), pp. 85-92.

6. Drake C, Roehrs T, Shambroom J, Roth T. Caffeine Effects On Sleep Taken 0, 3, Or 6 Hours Before Going To Bed. Journal of Clinical Sleep Medicine. 2013; 9 (11): 1195-200.

7. Ernawati, Sudaryanto A. Faktor-Faktor Yang Berhubungan Dengan Terjadinya Insomnia Pada Lanjut Usia di Desa Gayam Kecamatan Sukoharjo Kabupaten Sukoharjo. Jawa Tengah. Universitas Muhammadiyah Surakarta. 2010.

8. Fairuszita SB. Hubungan lamanya pemakaian gawai elektronik sebelum tidur dengan kualitas tidur mahasiswa profesi dokter universitas andalas angkatan 2014-2015. Padang: Universitas Andalas; 2017.

9. Gonzalez MMC, Jones GA. Circadian Regulation of Arousal: Role of the Noradrenergic Locus Coeruleus System and Light Exposure. SLEEP. 2006; 29(10):1327-36.

10. Heo JY, Kim K, Fava M, Mischoulon D, Papakostas GI, Kim MJ, et al. Effects of smartphone use with and without blue light at night in healthy adults: a randomized, double-blind, cross-over, placebocontrolled comparison. Psychiatric Research. 2016 Des 9; 1-29.

11. Hernanda Y. Hubungan lama penggunaan smartphone dengan kesehatan mental remaja di smk negeri 5 
padang tahun 2017. Padang: Universitas Andalas; 2017.

12. Holst A (2019). Number of smartphone users worldwide from 2016 to 2021 (in billions). Statista. https://www.statista.com/statistics/330695/numberof-smartphone-users-worldwide/. Diakses November 2019.

13. Japardi I. Gangguan tidur. USU Digital Library. 2002:111.

14. Jarmi A, Rahayuningsih SI. Hubungan Penggunaan Gadget Dengan Kualitas Tidur pada Remaja. 2017: 1-7.

15. Keswara UR , Syuhada N , Wahyudi WT. Perilaku penggunaan gadget dengan kualitas tidur pada remaja. Holistik Jurnal Kesehatan. 2019 September; 13(3): 233-9.

16. King DL, Delfabbro PH, Zwaans T, Kaptis D. Sleep Interference Effects of Pathological Electronic Media Use during Adolescence. Int J Ment Health Addiction. 2014; 12:21-35.

17. Kominfo. 2015. Indonesia raksasa teknologi digital asia. https://kominfo.go.id/content/detail/6095/indonesia -raksasa-teknologi-digital-asia/0/sorotan_media. Diakses Oktober 2019.

18. Ong HO, Mahode AA, Ramadhani D, editors. Fisiologi manusia dari sel ke sistem. Jakarta : EGC; 2016.

19. Potter PA, Perry G.A. Fundamental of nursing. Edisi 7.Jakarta : EGC; 2010.

20. Przybylski AK, Weinstein N. A Large-Scale Test of the Goldilocks Hypothesis: Quantifying the Relations Between Digital-Screen Use and the Mental Well-Being of Adolescents. Psychological Science. 2017; 28(2): 204-15.

21. Renard G, Leid J. The dangers of blue light: True story!. Elsevier. 2016 Feb 16; 1-6.

22. Riaraly PAK. Hubungan kelelahan dengan kualitas tidur pada mahasiswa profesi fakultas keperawatan universitas andalas. Padang: Universitas Andalas; 2017.

23. Sulistiyani C. Beberapa Faktor Yang Berhubungan Dengan Kualitas Tidur Pada Mahasiswa Fakultas Kesehatan Masyarakat Universitas Diponegoro Semarang. Jurnal Kesehatan Masyarakat. 2012; 1(2): 280-92.

24. Syahdrajat T. Panduan Penelitian untuk Skripsi Kedokteran \& Kesehatan. Jakarta: Dian Rakyat Jakarta; 2019.

25. Universitas Indonesia Library. 2015. Uji validitas dan reliabilitas instrumen pittsburgh sleep quality index versi Bahasa Indonesia $=$ Test validity and reliability of the instrument pittsburgh sleep quality index Indonesia language version. http://lib.ui.ac.id/detail?id=20404062\&lokasi=lokal. Diakses Juni 2020.

26. Wood B, Rea MS, Plitnick B, Figueiro MG. Light level and duration of exposure determine the impact of selfluminous tablets on melatonin suppression. Applied Ergonomics. 2013; 44: 237-40. 